ORIGINAL ARTICLE

\title{
Synergy between the C2 allele of transferrin and the C282Y allele of the haemochromatosis gene (HFE) as risk factors for developing Alzheimer's disease
}

\author{
K J H Robson*, D J Lehmann*, V L C Wimhurst*, K J Livesey, M Combrinck, A T Merryweather- \\ Clarke, D R Warden, A D Smith
}

J Med Genet 2004;41:261-265. doi: 10.1136/img.2003.015552

See end of article for authors' affiliations

.....................

Correspondence to:

Dr K Robson, MRC

Molecular Haematology

Unit, Weatherall Institute of

Molecular Medicine, John

Radcliffe Hospital,

Headington, Oxford OX3

9DS, UK; kathryn.robson@

imm.ox.ac.uk

Revised version received

11 December 2003

Accepted for publication

10 January 2004
Background: There is evidence that iron may play a role in the pathology of Alzheimer's disease (AD). There may be genetic factors that contribute to iron deposition resulting in tissue damage thus exacerbating $A D$.

Methods: We have genotyped 269 healthy elderly controls, 191 cases with definite or probable AD, and 69 with mild cognitive impairment (MCl) from the OPTIMA cohort.

Results: We have examined the interaction between the C2 variant of the transferrin (TF) gene and the C282Y allele of the haemochromatosis (HFE) gene as risk factors for developing AD. Our results showed that each of the two variants was associated with an increased risk of $A D$ only in the presence of the other. Neither allele alone had any effect. Carriers of both variants were at 5 times greater risk of $A D$ compared with all others. The interaction was significant by logistic regression $(p=0.014)$ and by synergy factor analysis $(p=0.015$, synergy factor $=5.1)$. Further, carriers of these two alleles plus apolipoprotein $E \varepsilon 4$ (APOE4) were at still higher risk of $A D$ : of the 14 tri-carriers of the three variants, identified in this study, 12 had $A D$ and two $M C l$.

Conclusion: We suggest that the combination of TF C2 and HFE C282Y may lead to an excess of redoxactive iron and the induction of oxidative stress in neurones, which is exacerbated in carriers of APOE4. Since $4 \%$ of Northern Europeans carry the two iron-related variants and since iron overload is a treatable condition, these results merit replication.
$\mathrm{T}$ here is evidence of iron misregulation ${ }^{1-3}$ (reviewed in Thompson $e t$ al $^{4}$ and Ke and Qian ${ }^{5}$ ) and of oxidative stress (reviewed in Christen ${ }^{6}$, Perry et al $^{7}$ and Praticò ${ }^{8}$ ), partly due to redox-active iron, ${ }^{39}$ in brains of patients with Alzheimer's disease $(\mathrm{AD})$. The products of the transferrin $(T F)$ and haemochromatosis (HFE) genes interact in iron metabolism by competing for binding the transferrin receptor. ${ }^{10}$ The combination of the TF C2 and HFE C282Y variants may result in an excess of free iron and in the generation of free radicals in neurones (see Discussion).

Both the TF C2 and HFE C282Y variants, as well as the HFE H63D polymorphism, have been investigated as potential risk factors for $\mathrm{AD}$, with mixed results (TF $\mathrm{C} 2,{ }^{11-15} \mathrm{HFE} \mathrm{H} 63 \mathrm{D}$ and $\left.\mathrm{C}^{2} 82 \mathrm{Y}^{15-20}\right)$. The interaction between TF $\mathrm{C} 2$ and HFE C282Y has not been specifically studied, to our knowledge. Sporadic $\mathrm{AD}$ is a complex disease. Each susceptibility gene is thus subject to interactions, which limit its overall association with disease. ${ }^{21}$ We therefore examined the interaction between TF $\mathrm{C} 2$ and HFE $\mathrm{C} 282 \mathrm{Y}$ in $\mathrm{AD}$ and in mild cognitive impairment $(\mathrm{MCI})^{22}$ in the cohort of the Oxford Project to Investigate Memory and Ageing (OPTIMA). We also looked for an interaction with apolipoprotein E $\varepsilon 4$ (APOE4), as it is not only an established risk factor for $\mathrm{AD}^{23}{ }^{24}$ but is associated with oxidative stress. ${ }^{25}$

\section{METHODS}

All 191 cases of AD (108 women), 69 cases of MCI (30 women) as defined by Petersen et al ${ }^{22}$, and 269 controls (139 women) were Caucasians from the OPTIMA cohort. This is a longitudinal, observational cohort of dementia patients and elderly controls, drawn from the Oxford region and followed

*The first three authors should be regarded as joint first authors. for up to 15 years. All participants have undergone annual assessments, including a detailed history, physical examination, blood tests, and computerised tomography (CT) and single photon emission tomography (SPET) scans (for measuring cerebral blood flow), as well as 6-monthly cognitive assessments using CAMDEX. ${ }^{26}$ Post mortem examinations are performed, where consent is given, which is normally the case.

Mean age of onset of $\mathrm{AD}$ was $70.5 \pm 9.2$ years and of death or of last examination of controls was $76.1 \pm 8.9$ years. Of the $\mathrm{AD}$ cases, 111 were neuropathologically confirmed by CERAD $^{27}$ criteria (96 "definite" and 15 "probable") and 80

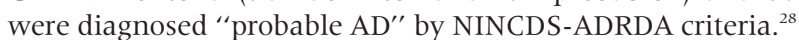
Possible autosomal dominant cases were excluded, based on family history. MCI cases were based on the criteria of Petersen et al. ${ }^{22}$ All 269 controls were without cognitive impairment and with CAMCOG scores $>80 .^{26}$

Genotyping of TF C2 was performed as previously described $^{29}$ with the following modifications. The number of PCR cycles was increased from 35 to 40, BstEII (New England Biolabs) digestion was performed at $60^{\circ} \mathrm{C}$ and fragments were resolved using 3\% NuSieve:1\% agarose gels (Flowgen) buffered with Tris borate EDTA pH 8.3.

Abbreviations: $A D$, Alzheimer's disease; CERAD, The Consortium to Establish a Registry for Alzheimer's Disease; $\mathrm{Cl}$, confidence interval; $H F E$, the haemochromatosis gene; IRP, iron regulatory protein; $M C l$, mild cognitive impairment; NINCDS-ADRDA, National Institute of Neurological, Communicative Diseases and Stroke-Alzheimer's Disease and Related Diseases Association; NS, not significant; OPTIMA, the Oxford Project to Investigate Memory and Ageing; OR, odds ratio; TF, the transferrin gene; TfR 1, transferrin receptor 1 
HFE genotyping was carried out as described ${ }^{30}$ using the modified primer for the C282Y amplification. ${ }^{31}$ Standard PCR methods were used for APOE. ${ }^{32}$ All genotyping was undertaken blind to diagnosis. Unadjusted odds ratios (OR) were by Fisher's exact test. Adjusted odds ratios were by logistic regression analysis using " $\mathrm{R}^{\prime \prime} .^{33}$ Synergy factor analysis used the method of Lehmann et al. ${ }^{21}$

\section{RESULTS}

A total of 529 individuals (191 AD, 69 MCI, and 269 controls) were typed for the $\mathrm{C} 282 \mathrm{Y}$ and H63D alleles of HFE and the $\mathrm{C} 2$ allele of $T F$.

Table 1 shows the genotypes of TF C2 and of HFE C282Y and H63D in AD, in MCI, and in controls. HFE C282Y and H63D genotypes were in Hardy-Weinberg equilibrium; TF C2 genotypes were not in Hardy-Weinberg equilibrium in the control population, as may occur with disease-related genes, for example with the $D C P 1$ gene in several $\mathrm{AD}$ association studies. ${ }^{34}$ Control frequencies of the TF C2 and HFE C282Y and $\mathrm{H} 63 \mathrm{D}$ alleles were 21,6 , and $15 \%$, respectively, which are typical of Northern European populations. ${ }^{11} 1330$

We first examined the association with AD of each of TF C2 and HFE C282Y when stratified for the presence of the other. Neither variant was associated with $\mathrm{AD}$ without the other, nor overall, but each increased the risk of $\mathrm{AD}$ in the presence of the other (tables 2 and 3).

We then compared carriers of both variants with all other subjects. Table 4 shows the unadjusted odds ratios of $\mathrm{AD}$ and MCI. The unadjusted odds ratio (OR) of AD for bi-carriers of HFE $\mathrm{C} 282 \mathrm{Y}$ and TF $\mathrm{C} 2$ versus all others was $4.8(95 \%$ confidence interval $(\mathrm{CI}) 1.7$ to $13.4, \mathrm{p}=0.001$ ) and, after adjusting for age, gender, systolic blood pressure, and for years of education, it was 5.4 (CI 1.5 to $19.9, \mathrm{p}=0.01$ ). There was a trend, not statistically significant, for an association of MCI with bi-carriers.

Formal tests of interactions are logistic regression and synergy factor analysis. ${ }^{35}$ The former gave $\mathrm{p}=0.014$ for the interaction in $\mathrm{AD}$ risk between $H F E \mathrm{C} 282 \mathrm{Y}$ and $T F \mathrm{C} 2$, controlling for age and for gender, and $p=0.047$, when also controlling for systolic blood pressure and for years of education. The synergy factor for these two variants in $A D$ risk was 5.1, with $\mathrm{p}=0.015$.

Although the association was significant in women (OR of $\mathrm{AD}$ for bi-carriers $=7.0,95 \%$ CI 1.5 to $33, \mathrm{p}=0.006$ ) and not in men $(\mathrm{OR}=3.3,95 \% \mathrm{CI} 0.8$ to $14, \mathrm{p}=0.16$, NS $)$, the interaction with gender was not significant by logistic regression analysis $(\mathrm{p}=0.4)$. There was thus no evidence of an interaction with gender, nor with age (data not shown). Nor did carrying either variant or both affect the mean onset age of $\mathrm{AD}$, which was 70.7 years for bi-carriers and 70.4 years for all others.

Table 1 TF C2 and HFE C282Y and H63D genotypes in $A D$, in $\mathrm{MCl}$, and in controls

\begin{tabular}{|c|c|c|c|c|c|c|}
\hline \multirow[b]{2}{*}{ Genotypes } & \multicolumn{2}{|l|}{$A D$} & \multicolumn{2}{|l|}{$\mathrm{MCl}$} & \multicolumn{2}{|c|}{ Controls } \\
\hline & $\%$ & (n) & $\%$ & (n) & $\%$ & (n) \\
\hline TF C2-negative & 57.6 & (110) & 71.0 & (49) & 66.5 & (179) \\
\hline TF C2 heterozygotes & 34.0 & (65) & 24.6 & (17) & 25.7 & (69) \\
\hline TF C2 homozygotes & 8.4 & (16) & 4.3 & (3) & 7.8 & (21) \\
\hline HFE C282Y-negative & 84.3 & (161) & 75.4 & (52) & 88.1 & (237) \\
\hline HFE C282Y heterozygotes & 15.7 & (30) & 23.2 & (16) & 11.5 & (31) \\
\hline HFE C282Y homozygotes & 0 & (0) & 1.4 & (1) & 0.4 & (1) \\
\hline HFE H63D-negative & 72.2 & (138) & 75.4 & (52) & 72.1 & (194) \\
\hline HFE H63D heterozygotes & 26.2 & (50) & 24.6 & (17) & 24.9 & (67) \\
\hline $\begin{array}{l}\text { HFE H63D homozygotes } \\
\text { Total number }\end{array}$ & 1.6 & $\begin{array}{l}\text { (3) } \\
(191)\end{array}$ & 0 & $\begin{array}{l}\text { (0) } \\
(69)\end{array}$ & 3.0 & $\begin{array}{l}\text { (8) } \\
(269)\end{array}$ \\
\hline
\end{tabular}

AD, Alzheimer's disease; TF and HFE, the transferrin and

haemochromatosis genes, respectively; $\mathrm{MCl}$, mild cognitive impairment.
Table 2 Risk of AD associated with the HFE C282Y allele, by TF C2 carrier status

\begin{tabular}{lrccll}
\hline Subgroup & $\begin{array}{l}\text { AD } \\
(\boldsymbol{n})\end{array}$ & $\begin{array}{l}\text { Controls } \\
(\boldsymbol{n})\end{array}$ & OR & $(95 \% \mathrm{Cl})$ & $\mathbf{p}$ \\
\hline TF C2-positive & 81 & 90 & 3.2 & $(1.2-8.3)$ & 0.016 \\
TF C2-negative & 110 & 179 & 0.8 & $(0.4-1.6)$ & $0.6, \mathrm{NS}$ \\
All & 191 & 269 & 1.3 & $(0.8-2.2)$ & $0.35, \mathrm{NS}$
\end{tabular}

$A D$, Alzheimer's disease; $\mathrm{Cl}$, confidence interval; NS, not significant; $O R$, odds ratio.

Table 3 Risk of AD associated with the TF C2 allele, by HFE C282Y carrier status

\begin{tabular}{lcccll}
\hline Subgroup & $\begin{array}{l}\text { AD } \\
(\boldsymbol{n})\end{array}$ & $\begin{array}{l}\text { Controls } \\
(\boldsymbol{n})\end{array}$ & OR & $(95 \% \mathrm{Cl})$ & $\mathbf{p}$ \\
\hline HFE C282Y-positive & 30 & 32 & 4.1 & $(1.6-10.5)$ & 0.004 \\
HFE C282Y-negative & 161 & 237 & 1.1 & $(0.8-1.6)$ & $0.5, \mathrm{NS}$ \\
All & 191 & 269 & 1.3 & $(0.96-1.8)$ & $0.09, \mathrm{NS}$ \\
\hline
\end{tabular}

$A D$, Alzheimer's disease; $\mathrm{Cl}$, confidence interval; NS, not significant; $O R$, odds ratio.

We also examined the interaction with APOE4. Tri-carriers of HFE C282Y, TF C2 and APOE4 appeared at still greater risk of $\mathrm{AD}$ : OR (versus all others) $=37.5,95 \%$ CI 2.2 to 638 , $\mathrm{p}<0.0001$. Of the 14 tri-carriers of the three variants, identified in this study, 12 had AD and two had MCI.

We found no association of the HFE H63D variant with $\mathrm{AD}$, or with MCI, either overall or in two-way interaction with either TF C2 or APOE4 (data not shown). But all five tricarriers of the $\mathrm{C} 282 \mathrm{Y}$ and $\mathrm{H} 63 \mathrm{D}$ variants of HFE plus TF $\mathrm{C} 2$ either had $\mathrm{AD}(n=4)$ or MCI $(n=1)$. The OR of $\mathrm{AD}$ for these tri-carriers versus all others was 12.9 (95\% CI 0.7 to 242, $\mathrm{p}=0.03)$.

\section{DISCUSSION}

Our results showed that in the Oxford population, neither TF $\mathrm{C} 2$ nor HFE C282Y alone was associated with $\mathrm{AD}$, yet bicarriers were at 5 times greater risk of $\mathrm{AD}$. Carrying $H F E$ H63D as well may further increase the risk. Furthermore, tricarriers of HFE C282Y, TF C2 and APOE4 may be at still greater risk. Why should this be?

\section{Biology of the HFE C282Y, HFE H63D and TF C2 proteins}

Once transferrin binds to transferrin receptor 1 , the complex is internalised and iron is released, as the lower $\mathrm{pH}$ of the endosome is reached. ${ }^{36}$ The wild type HFE protein was found to bind transferrin receptor 1 and to decrease the receptor's affinity for transferrin. ${ }^{10}$ The $\mathrm{C} 282 \mathrm{Y}$ variant, however, fails to bind to transferrin receptor 1 (TfRl), leaving transferrin free to bind TfRl with high affinity. The H63D variant may also fail to reduce the affinity of transferrin for TfRl, even though this variant does bind to TfR $1 .{ }^{10}$ The increased binding of

Table 4 Risk of $A D$ and of $M C I$ for bi-carriers of HFE C282Y and TF C2

\begin{tabular}{lccc}
\hline & AD & MCI & Controls \\
\hline Bi-carriers (n) & 16 & 4 & 5 \\
All others (n) & 175 & 65 & 264 \\
OR (95\% CI) & $4.8(1.7$ to 13) & $3.2(0.8$ to 12) & \\
$\mathrm{p}$ & 0.001 & $0.09, \mathrm{NS}$ & \\
\hline
\end{tabular}

$A D$, Alzheimer's disease; $\mathrm{Cl}$, confidence interval; $\mathrm{MCl}$, mild cognitive impairment; NS, not significant; OR, odds ratio. 
transferrin to TfRl raises the risk of peripheral iron overload, ${ }^{37-40}$ although its effect on iron metabolism in the brain is largely unknown.

The TF C2 variant has been reported to be associated with various conditions related to free radicals, suggesting differences in iron metabolism of TF $\mathrm{C} 2$ carriers. ${ }^{41}$ One study found that total iron-binding capacity was lower in TF C2 carriers. ${ }^{42}$ This suggests that TF C2 may have a lower affinity for iron. We therefore suggest that in bi-carriers of $H F E$ $\mathrm{C} 282 \mathrm{Y}$ and TF C2 it is possible that more transferrin-receptor complexes are internalised by neurones (due to HFE C282Y) and iron is more readily released in endosomes (due to $T F$ $\mathrm{C} 2$ ), leading to higher levels of free iron and the production of free radicals, which damage the membranes of vulnerable neurones. Alternatively, if the total iron-binding capacity is lower in TF C2 carriers there may be more free iron which could also result in tissue damage.

\section{Iron and AD}

Iron is essential for the activity of many enzymes and oxygen carriers, but its misregulation in the brain can lead to oxidative stress and neurodegeneration. Ferrous iron, the redox-active form, can react with oxygen to produce the superoxide radical and react with hydrogen peroxide to generate the hydroxyl radical, which can damage every category of macromolecule. There are several well-studied examples of neurodegenerative conditions due to mutations in genes of iron metabolism, which lead to oxidative stress. ${ }^{5}$

There are numerous signs of iron misregulation in AD. Non-haem and redox-active iron is found in tangles and in the neurites of plaques in the AD brain. ${ }^{343}$ The expression and distribution in the brain of various proteins of iron metabolism change during ageing and in $\mathrm{AD}$, for example transferrin, ${ }^{12}$ TfRl $^{44}$ ferritin, ${ }^{145}$ lactotransferrin, ${ }^{46}$ haem oxygenase- $1,{ }^{47}$ and iron regulatory protein 2 (IRP2). ${ }^{48}$ The ferritin:iron ${ }^{49}$ and transferrin:iron ratios ${ }^{2}$ both decrease in certain regions of the $\mathrm{AD}$ brain. The role of iron regulatory proteins (IRPs) is to maintain cellular iron homeostasis by adjusting the ratio of the expression of ferritin to that of TfRl, according to the cell's needs for iron storage and uptake. This iron homeostasis may be lost in $\mathrm{AD}$, where it has been reported that IRPs may form stable complexes with iron response elements in the $5^{\prime}$ or $3^{\prime}$ untranslated regions of mRNAs. ${ }^{50}$ This could result in increased synthesis of TfRl and decreased expression of ferritin, leading to increased cellular uptake of iron with reduced storage. Perry et al have suggested that metals bound to cytoplasmic RNA are the main sites of redox activity in neurones in $\mathrm{AD}$. They highlighted the large quantity of cytoplasmic RNA in pyramidal neurones. A type II iron response element has been found in the $5^{\prime}$ untranslated region of the amyloid precursor protein. ${ }^{51}$ This suggests that iron is intimately involved in regulating a protein that is known to be involved in $\mathrm{AD}$.

\section{Oxidative stress in AD}

There is ample evidence of oxidative damage in $\mathrm{AD}$ (reviewed in Christen ${ }^{6}$, Perry et $a l^{7}$ and Praticò ${ }^{8}$ ), particularly to lipids ${ }^{52-54}$ but also to proteins, ${ }^{55-58} \mathrm{RNA}^{59}{ }^{60}$ and DNA, ${ }^{58}$ including mitochondrial DNA, ${ }^{62}$ although there is also some contrary evidence. ${ }^{58}{ }^{63}$ The post mortem evidence, which has certain limitations, has recently been supported by studies in living patients using the cerebrospinal fluid markers, $\mathrm{F}_{2}$-isoprostanes $^{64}$ (reviewed in Praticò $^{8}$ ). It is thought that in AD, mitochondria supply the precursors of hydroxyl radicals, that is, redox-active iron and hydrogen peroxide. ${ }^{7965}$ The lack of a strong compensatory increase in antioxidant enzymes ${ }^{55} 56$ may be due to the role of $\beta$-amyloid peptides in inactivating them. ${ }^{66} 67$
It has been suggested that vulnerable neurones are more sparsely myelinated and are therefore subject to higher energy turnover and are hence less resistant to oxidative stress. ${ }^{68}$ It may be relevant that myelination demands iron and oligodendrocytes contain high levels of iron. ${ }^{69} 70$ Two groups have proposed, for differing reasons, that oxidative stress is an early event in $\mathrm{AD}$, probably preceding $\beta$-amyloid accumulation. ${ }^{8}$

\section{Oxidative stress and APOE4}

Apolipoprotein E (apoE) has antioxidant activity at physiological levels, in the order E2>E3>E4, as was shown in cell cultures by Miyata and Smith. ${ }^{25}$ The antioxidant activity of apoE has been supported by studies in mice ${ }^{72} 73$ and the association of APOE4 with oxidative stress has been shown in $\mathrm{AD}$ patients. ${ }^{72}{ }^{74-76}$ It has been suggested that apoE acts as an antioxidant by sequestering metals. ${ }^{25}$ It was found that apoE bound copper, zinc, and bi- and trivalent iron, but not aluminium nor certain other metals. It is particularly relevant that, unlike copper and zinc, both ferrous and ferric forms of iron remained bound to apoE even when $\mathrm{pH}$ was reduced to 2.5. ${ }^{25}$ This suggests that apoE could stay attached to iron, even after the latter had dissociated from transferrin (see above), thus enabling apoE2 and E3, but not E4, to act as antioxidants if they exist in the same intracellular compartment.

\section{Mild cognitive impairment ( $\mathrm{MCl}$ )}

If our above hypothesis is correct and if oxidative stress is an early event in $\mathrm{AD}$, as suggested, ${ }^{871}$ then we should see some sign of the association in MCI. We found a tendency for bicarriers of HFE C282Y and TF C2 to be at risk for MCI, in line with their associations with $\mathrm{AD}$ (table 4). Also, in both sets of tri-carriers examined (that is bi-carriers plus APOE4 and bicarriers plus HFE H63D), there were cases of $\mathrm{AD}$ and $\mathrm{MCI}$, but no controls whatsoever. These findings for MCI are consistent with our results for $\mathrm{AD}$ and with our hypothesis.

\section{CONCLUSIONS}

We suggest that bi-carriers of HFE $\mathrm{C} 282 \mathrm{Y}$ and TF $\mathrm{C} 2$ may be at higher risk of $\mathrm{AD}$, due to increased redox-active iron and therefore oxidative stress in the cytoplasm of vulnerable neurones. Carriers of APOE2 and APOE3 appear partially protected from this oxidative damage, but tri-carriers of the two iron-related variants plus APOE4 may be at very high risk of $\mathrm{AD}$

There have been many other reports of associations of $\mathrm{AD}$ with genes in the human major histocompatibility complex, ${ }^{77}$ but these have been conflicting. Although HFE $\mathrm{C} 282 \mathrm{Y}$ is in weak linkage disequilibrium with $H L A$-B7 and we ourselves had found an association of HLA-B7 with $\mathrm{AD},{ }^{77}$ that earlier finding was solely in APOE4-negative subjects, while our current result is mainly in APOE4 carriers. Although we cannot exclude linkage disequilibrium with other nearby genes or with those on the extended haplotype of $H F E$ $\mathrm{C} 282 \mathrm{Y}^{78}{ }^{79}$ we consider it unlikely that our present results are due to linkage disequilibrium with any of the classical HLA genes.

Our results may partly explain the conflicting reports of previous association studies of $\mathrm{AD}$ with TF C2 and with HFE $\mathrm{C} 282 \mathrm{Y}$, though the rarity of the latter allele outside populations of Northern European origin will also be a factor. ${ }^{30}{ }^{80}$ In general, the associations of susceptibility genes with complex diseases are limited by interactions with age, gender, other genes, and the environment. ${ }^{21}$ It is unlikely that the roles of these genes will be understood without investigating these interactions, which may differ by ethnic group. 
If replicated, the findings will also contribute to our understanding of the causality of $\mathrm{AD}$ and of the roles of redox-active iron, of oxidative stress, and of APOE 4 in that causality. They may help to explain why APOE4 increases the risk of $\mathrm{AD},{ }^{23}{ }^{24}$ but has not generally been found to contribute to faster progression of the disease, ${ }^{81} 82$ if oxidative stress is indeed an early event in $\mathrm{AD}$ as has been suggested. ${ }^{8} 72$

Furthermore, if it is also shown that bi-carriers of these variants suffer from iron overload, we note that that is a potentially treatable condition. Approximately $4 \%$ of Northern Europeans carry both variants.

\section{ACKNOWLEDGEMENTS}

We especially thank all patients and volunteers, members of OPTIMA, and the Department of Neuropathology, Radcliffe Infirmary. We thank Professor Sir David Weatherall for support and encouragement.

\section{Authors' affiliations}

K J H Robson, V L C Wimhurst, K J Livesey, A T Merryweather-Clarke, MRC Molecular Haematology Unit, Weatherall Institute of Molecular Medicine, Oxford OX3 9DS, UK

D J Lehmann, M Combrinck, D R Warden, A D Smith, Oxford Project to Investigate Memory and Ageing (OPTIMA), University Department of Pharmacology, Oxford OX1 3QT, UK

We are most grateful to Bristol Myers Squibb, the Medical Research Council, the Norman Collisson Foundation, and the Takayama Foundation for financial support. This work has been supported by EC contract QLRT 1999-02237.

Conflict of interest: none declared.

\section{REFERENCES}

1 Connor JR, Menzies SL, St Martin SM, Mufson EJ. A histochemical study of iron, transferrin, and ferritin in Alzheimer's diseased brains. J Neurosci Res 1992;31(1):75-83.

2 Loeffler DA, Connor JR, Juneau PL, Snyder BS, Kanaley L, DeMaggio AJ Nguyen $\mathrm{H}$, Brickman CM, LeWitt PA. Transferrin and iron in normal, Alzheimer's disease, and Parkinson's disease brain regions. J Neurochem 1995;65(2):710-24

3 Smith MA, Harris PL, Sayre LM, Perry G. Iron accumulation in Alzheimer disease is a source of redox-generated free radicals. Proc Natl Acad Sci U S A 1997;94(18):9866-8

4 Thompson KJ, Shoham S, Connor JR. Iron and neurodegenerative disorders. Brain Res Bull 2001;55(2):155-64.

$5 \mathrm{Ke} \mathrm{Y,} \mathrm{Qian} \mathrm{ZM.} \mathrm{Iron} \mathrm{misregulation} \mathrm{in} \mathrm{the} \mathrm{brain:} \mathrm{a} \mathrm{primary} \mathrm{cause} \mathrm{of}$ neurodegenerative disorders. Lancet Neurol 2003;2:246-53.

6 Christen Y. Oxidative stress and Alzheimer disease. Am J Clin Nutr 2000;71(2):621S-9S

7 Perry G, Nunomura A, Hirai K, Zhu X, Perez M, Avila J, Castellani RJ Atwood CS, Aliev G, Sayre LM, Takeda A, Smith MA. Is oxidative damage the fundamental pathogenic mechanism of Alzheimer's and other neurodegenerative diseases? Free Radic Biol Med 2002;33(1 1):1475-9.

8 Praticò D. Alzheimer's disease and oxygen radicals: new insights. Biochem Pharmacol 2002;63(4):563-7.

9 Perry G, Taddeo MA, Petersen RB, Castellani RJ, Harris PL, Siedlak SL, Cash AD, Liu Q, Nunomura A, Atwood CS, Smith MA. Adventitiously-bound redox active iron and copper are at the center of oxidative damage in Alzheimer disease. Biometals 2003;16(1):77-81.

10 Feder JN, Penny DN, Irrinki A, Lee VK, Lebrón JA, Watson N, Tsuchihashi Z, Sigal E, Bjorkman PJ, Schatzman RC. The hemochromatosis gene product complexes with the transferrin receptor and lowers its affinity for ligand binding. Proc Natl Acad Sci U S A 1998:95:1472-7.

11 van Rensburg SJ, Carstens ME, Potocnik FC, Aucamp AK, Taljaard JJ. Increased frequency of the transferrin C2 subtype in Alzheimer's disease. Neuroreport 1993;4(11):1269-71.

12 Namekata K, Imagawa M, Terashi A, Ohta S, Oyama F, Ihara Y. Association of transferrin C2 allele with late-onset Alzheimer's disease. Hum Genet 1997; 101(2):126-9

13 Van Landeghem GF, Sikström C, Beckman LE, Adolfsson R, Beckman L. Transferrin C2, metal binding and Alzheimer's disease. Neuroreport 1998;9(2): 177-9.

14 Hussain RI, Ballard CG, Edwardson JA, Morris CM. Transferrin gene polymorphism in Alzheimer's disease and dementia with Lewy bodies in humans. Neurosci Lett 2002;317(1):13-6.

15 Lleò A, Blesa R, Angelopoulos C, Pastor-Rubio P, Villa M, Oliva R, Bufill E. Transferrin C2 allele, haemochromatosis gene mutations, and risk for Alzheimer's disease. J Neurol Neurosurg Psychiatry 2002;72(6):820-1.

16 Moalem S, Percy ME, Andrews DF, Kruck TP, Wong S, Dalton AJ, Mehta P, Fedor B, Warren AC. Are hereditary hemochromatosis mutations involved in Alzheimer disease? Am J Med Genet 2000;93(1):58-66.
17 Sampietro M, Caputo L, Casatta A, Meregalli M, Pellagatti A, Tagliabue J, Annoni G, Vergani C. The hemochromatosis gene affects the age of onset of sporadic Alzheimer's disease. Neurobiol Aging 2001;22(4):563-8.

18 Candore G, Licastro F, Chiappelli M, Franceschi C, Lio D, Rita Balistreri C, Piazza G, Colonna-Romano G, Grimaldi LM, Caruso C. Association between the HFE mutations and unsuccessful ageing: a study in Alzheimer's disease patients from Northern Italy. Mech Ageing Dev 2003;124(4):525-8.

19 Combarros O, Garcia-Román M, Fontalba A, Fernández-Luna JL, Llorca J, Infante J, Berciano J. Interaction of the H63D mutation in the hemochromatosis gene with the apolipoprotein E epsilon 4 allele modulates age of onset of Alzheimer's disease. Dement Geriatr Cogn Disord 2003;15(3): 151-4.

20 Pulliam JF, Jennings CD, Kryscio RJ, Davis DG, Wilson D, Montine TJ Schmitt FA, Markesbery WR. Association of HFE mutations with neurodegeneration and oxidative stress in Alzheimer's disease and correlation with APOE. Am J Med Genet 2003;119B(1):48-53.

21 Lehmann DJ, Williams J, McBroom J, Smith AD. Using meta-analysis to explain the diversity of results in genetic studies of late-onset Alzheimer's disease and to identify high-risk subgroups. Neuroscience 2001; 108(4):541-54

22 Petersen RC, Smith GE, Waring SC, Ivnik RJ, Tangalos EG, Kokmen E. Mild cognitive impairment: clinical characterization and outcome. Arch Neurol 1999;56(3):303-8

23 Saunders AM, Strittmatter WJ, Schmechel D, St George-Hyslop PH, PericakVance MA, Joo SH, Rosi BA, Gusella JF, Crapper-MacLachlan DR, Allberts MJ, Hulette C, Crain B, Goldgaber D, Roses AD. Association of apolipoprotein E allele epsilon 4 with late-onset familial and sporadic Alzheimer's disease. Neurology 1993;43(8): 1467-72.

24 Farrer LA, Cupples LA, Haines JL, Hyman B, Kukull WA, Mayeux R, Myers RH, Pericak-Vance MA, Risch N, van Duijn CM. Effects of age, sex, and ethnicity on the association between apolipoprotein $\mathrm{E}$ genotype and Alzheimer disease. A meta-analysis. APOE and Alzheimer Disease Meta Analysis Consortium. JAMA 1997;278(16):1349-56.

25 Miyata M, Smith JD. Apolipoprotein E allele-specific antioxidant activity and effects on cytotoxicity by oxidative insults and beta-amyloid peptides. Nat Genet 1996;14(1):55-61.

26 Roth M, Huppert FA, Tym E, Mountjoy CQ. CAMDEX: The Cambridge examination for mental disorders of the elderly. Cambridge: Cambridge University Press, 1988.

27 Mirra SS, Heyman A, McKeel D, Sumi SM, Crain BJ, Brownlee LM, Vogel FS Hughes JP, van Belle G, Berg L. The Consortium to Establish a Registry for Alzheimer's Disease (CERAD). Part II. Standardization of the neuropathologic assessment of Alzheimer's disease. Neurology 1991;41(4):479-86.

28 McKhann G, Drachman D, Folstein M, Katzman R, Price D, Stadlan EM Clinical diagnosis of Alzheimer's disease: report of the NINCDS-ADRDA Work Group under the auspices of Department of Health and Human Services Task Force on Alzheimer's Disease. Neurology 1984;34(7):939-44.

29 Namekata K, Oyama F, Imagawa M, lhara Y. Human transferrin (Tf): a single mutation at codon 570 determines Tf $\mathrm{C} 1$ or Tf $\mathrm{C} 2$ variant. Hum Genet 1997; 100(3-4):457-8.

30 Merryweather-Clarke AT, Pointon JJ, Shearman JD, Robson KJH. Global prevalence of putative haemochromatosis mutations. J Med Genet 1997;34:275-8.

31 Merryweather-Clarke AT, Pointon JJ, Shearman JD, Robson KJH, Jouanolle AM, Mosser A, David V, Le Gall J-Y, Halsall DJ, Elsey TS, Kelly A Cox TM, Clare M, Bomford A, Vandwalle JL, Rochette J, Borot N, Coppin H, Roth M-P, Ryan E, Crowe J, Totaro A, Gasparini P, Roetto A, Camaschella C, Darke C, Wallace DF, Saeb-Parsy K, Dooley JS, Worwood M, Walker AP. Polymorphism in intron 4 of HFE does not compromise haemochromatosis mutation results. Nat Genet 1999;23:271.

32 Wenham PR, Price WH, Blandell G. Apolipoprotein E genotyping by onestage PCR. Lancet 1991;337(8750): 1158-9.

33 Ihaka R, Gentleman R. R: a language for data analysis and graphics. J Comput Graph Stat 1996:5:299-314.

34 Buss S, Muller-Thomsen T, Hock C, Alberici A, Binetti G, Nitsch RM, Gal A, Finckh $U$. No association between DCP1 genotype and late-onset Alzheimer disease. Am J Med Genet 2002;114(4):440-5.

35 Lehmann D, Johnston C, Cortina Borja M, Smith A. Age influences the synergy between butyrylcholinesterase $\mathrm{K}$ variant and apolipoprotein $\mathrm{E} e 4$ in late-onset Alzheimer's disease. In: Doctor B, Quinn D, Rotundo R, eds. Structure and function of cholinesterases and related proteins. New York: Plenum, 1998:159-66.

36 Dautry-Varsat A, Ciechanover A, Lodish HF. pH and the recycling of transferrin during receptor-mediated endocytosis. Proc Natl Acad Sci U S A 1983;80(8):2258-62.

37 Burt MJ, George PM, Upton JD, Collett JA, Frampton CM, Chapman TM, Walmsley TA, Chapman BA. The significance of haemochromatosis gene mutations in the general population: implications for screening. Gut 1998;43(6):830-6

38 Merryweather-Clarke AT, Worwood M, Parkinson L, Mattock C, Pointon JJ, Shearman JD, Robson KJH. The effect of HFE mutations on serum ferritin and transferrin saturation in the Jersey population. $\mathrm{Br} J$ Haematol 1998;101:369-73.

39 Phatak PD, Ryan DH, Cappuccio J, Oakes D, Braggins C, Provenzano K, Eberly S, Sham RL. Prevalence and penetrance of HFE mutations in 4865 unselected primary care patients. Blood Cells Mol Dis 2002;29(1):41-7.

40 Niajou OT, Houwing-Duistermaat JJ, Osborne RH, Vaessen N, Vergeer J, Heeringa J, Pols HA, Hofman A, van Duiin CM. A population-based study of the effect of the HFE C282Y and H63D mutations on iron metabolism. Eur J Hum Genet 2003;11(3):225-31.

41 Beckman L, Beckman G. Transferrin C2 as an enhancer of cyto- and genotoxic damage. Prog Clin Biol Res 1986;209B:221-4. 
42 Wong CT, Saha N. Effects of transferrin genetic phenotypes on total ironbinding capacity. Acta Haematol 1986;75(4):215-8.

43 Morris CM, Kerwin JM, Edwardson JA. Non-haem iron histochemistry of the normal and Alzheimer's disease hippocampus. Neurodegeneration 1994:3(4):267-75.

44 Connor JR, Menzies SL. Cellular management of iron in the brain. J Neurol Sci 1995; 134(suppl):33-44.

45 Connor JR, Snyder BS, Arosio P, Loeffler DA, LeWitt P. A quantitative analysis of isoferritins in select regions of aged, parkinsonian, and Alzheimer's diseased brains. J Neurochem 1995:65(2):717-24.

46 Kawamata T, Tooyama I, Yamada T, Walker DG, McGeer PL. Lactotransferrin immunocytochemistry in Alzheimer and normal human brain. Am J Pathol 1993;142(5):1574-85.

47 Schipper HM, Cisse S, Stopa EG. Expression of heme oxygenase- 1 in the senescent and Alzheimer-diseased brain. Ann Neurol 1995;37(6):758-68.

48 Smith MA, Wehr K, Harris PL, Siedlak SL, Connor JR, Perry G. Abnormal localization of iron regulatory protein in Alzheimer's disease. Brain Res 1998;788(1-2):232-6.

49 Fleming J, Joshi JG. Ferritin: isolation of aluminum-ferritin complex from brain. Proc Natl Acad Sci U S A 1987;84(22):7866-70.

50 Piñero DJ, Hu J, Connor JR. Alterations in the interaction between iron regulatory proteins and their iron responsive element in normal and Alzheimer's diseased brains. Cell Mol Biol (Noisy-le-grand) 2000;46(4):761-76.

51 Rogers JT, Randall JD, Cahill CM, Eder PS, Huang X, Gunshin H, Leiter L, McPhee J, Sarang SS, Utsuki T, Greig NH, Lahiri DK, Tanzi RE, Bush Al, Giordano T, Gullans SR. An iron-responsive element type II in the 5'untranslated region of the Alzheimer's amyloid precursor protein transcript. J Biol Chem 2002;277(47):45518-28.

52 Palmer AM, Burns MA. Selective increase in lipid peroxidation in the inferior temporal cortex in Alzheimer's disease. Brain Res 1994:645(1-2):338-42.

53 Lovell MA, Ehmann WD, Butler SM, Markesbery WR. Elevated thiobarbituric acid-reactive substances and antioxidant enzyme activity in the brain in Alzheimer's disease. Neurology 1995;45(8):1594-1601.

54 Sayre LM, Zelasko DA, Harris PL, Perry G, Salomon RG, Smith MA. 4-Hydroxynonenal-derived advanced lipid peroxidation end products are increased in Alzheimer's disease. J Neurochem 1997:68(5):2092-7.

55 Smith CD, Carney JM, Starke-Reed PE, Oliver CN, Stadtman ER, Floyd RA, Markesbery WR. Excess brain protein oxidation and enzyme dysfunction in normal aging and in Alzheimer disease. Proc Natl Acad Sci U S A 1991;88(23): 10540-3.

56 Hensley K, Hall N, Subramaniam R, Cole P, Harris M, Aksenov M, Aksenova M, Gabbita SP, Wu JF, Carney J'M, Lovell M, Markesbery WR, Butterfield A. Brain regional correspondence between Alzheimer's disease histopathology and biomarkers of protein oxidation. J Neurochem 1995:65(5):2146-56.

57 Good PF, Werner P, Hsu A, Olanow CW, Perl DP. Evidence of neuronal oxidative damage in Alzheimer's disease. Am J Pathol 1996;149(1):21-8.

58 Lyras L, Cairns NJ, Jenner A, Jenner P, Halliwell B. An assessment of oxidative damage to proteins, lipids, and DNA in brain from patients with Alzheimer's disease. J Neurochem 1997:68(5):2061-9.

59 Nunomura A, Perry G, Hirai K, Aliev G, Takeda A, Chiba S, Smith MA. Neuronal RNA oxidation in Alzheimer's disease and Down's syndrome. Ann N Y Acad Sci 1999;893:362-4.

60 Shan X, Tashiro H, Lin CL. The identification and characterization of oxidized RNAs in Alzheimer's disease. J Neurosci 2003;23(12):4913-21.

61 Gabbita SP, Lovell MA, Markesbery WR. Increased nuclear DNA oxidation in the brain in Alzheimer's disease. J Neurochem 1998;71(5):2034-40.

62 Mecocci P, MacGarvey U, Beal MF. Oxidative damage to mitochondrial DNA is increased in Alzheimer's disease. Ann Neurol 1994;36(5):747-51.

63 Hayn M, Kremser K, Singewald N, Cairns N, Nemethova M, Lubec B, Lubec $G$. Evidence against the involvement of reactive oxygen species in the pathogenesis of neuronal death in Down's syndrome and Alzheimer's disease. Life Sci 1996;59(7):537-44.

64 Montine KS, Kim PJ, Olson SJ, Markesbery WR, Montine TJ. 4-Hydroxy-2nonenal pyrrole adducts in human neurodegenerative disease. J Neuropathol Exp Neurol 1997;56(8):866-71.
65 Cash AD, Perry G, Ogawa O, Raina AK, Zhu X, Smith MA. Is Alzheimer's disease a mitochondrial disorder? Neuroscientist 2002;8(5):489-96

66 Hensley K, Carney JM, Mattson MP, Aksenova M, Harris M, Wu JF, Floyd RA, Butterfield DA. A model for beta-amyloid aggregation and neurotoxicity based on free radical generation by the peptide: relevance to Alzheimer disease. Proc Natl Acad Sci U S A 1994;91(8):3270-4.

67 Kim HC, Yamada K, Nitta A, Olariu A, Tran MH, Mizuno M, Nakajima A, Nagai T, Kamei H, Jhoo WK, Im DH, Shin EJ, Hjelle OP, Ottersen OP, Park SC, Kato K, Mirault ME, Nabeshima T. Immunocytochemical evidence that amyloid beta (1-42) impairs endogenous antioxidant systems in vivo. Neuroscience 2003;119(2):399-419.

68 Braak H, Del Tredici K, Schultz C, Braak E. Vulnerability of select neuronal types to Alzheimer's disease. Ann N Y Acad Sci 2000;924:53-61.

69 LeVine SM, Macklin WB. Iron-enriched oligodendrocytes: a reexamination of their spatial distribution. J Neurosci Res 1990;26(4):508-12.

70 Connor JR, Menzies SL. Relationship of iron to oligodendrocytes and myelination. Glia 1996;17(2):83-93.

71 Nunomura A, Perry G, Aliev G, Hirai K, Takeda A, Balraj EK, Jones PK, Ghanbari H, Wataya T, Shimohama S, Chiba S, Atwood CS, Petersen RB Smith MA. Oxidative damage is the earliest event in Alzheimer disease. J Neuropathol Exp Neurol 2001;60(8):759-67.

72 Ramassamy C, Averill D, Beffert U, Theroux L, Lussier-Cacan S, Cohn JS, Christen Y, Schoofs A, Davignon J, Poirier J. Oxidative insults are associated with apolipoprotein E genotype in Alzheimer's disease brain. Neurobiol Dis 2000;7(1):23-37.

73 Shea TB, Rogers E, Ashline D, Ortiz D, Sheu MS. Apolipoprotein E deficiency promotes increased oxidative stress and compensatory increases in antioxidants in brain tissue. Free Radic Biol Med 2002;33(8):1115-20.

74 Montine KS, Olson SJ, Amarnath V, Whetsell WO Jr, Graham DG Montine TJ. Immunohistochemical detection of 4-hydroxy-2-nonenal adducts in Alzheimer's disease is associated with inheritance of APOE4. Am J Pathol 1997; 150(2):437-43

75 Ramassamy C, Averill D, Beffert U, Bastianetto S, Theroux L, Lussier-Cacan S, Cohn JS, Christen Y, Davignon J, Quirion R, Poirier J. Oxidative damage and protection by antioxidants in the frontal cortex of Alzheimer's disease is related to the apolipoprotein E genotype. Free Radic Biol Med 1999;27(5-6):544-53.

76 Tamaoka A, Miyatake F, Matsuno S, Ishii K, Nagase S, Sahara N, Ono S, Mori H, Wakabayashi K, Tsuji S, Takahashi H, Shoji S. Apolipoprotein E allele-dependent antioxidant activity in brains with Alzheimer's disease. Neurology 2000;54(12):2319-21.

77 Lehmann DJ, Wiebusch H, Marshall SE, Johnston C, Warden DR, Morgan K, Schappert K, Poirier J, Xuereb J, Kalsheker N, Welsh KI, Smith AD. HLA class I, II and III genes in confirmed late-onset Alzheimer's disease. Neurobiol Aging $2001 ; 22(1): 71-7$.

78 Feder JN, Gnirke A, Thomas W, Tsuchihashi Z, Ruddy DA, Basava A Dormishian F, Domingo Jr R, Ellis MC, Fullan A, Hinton LM, Jones NL, Kimmel BE, Kronmal GS, Laver P, Lee VK, Loeb DB, Mapa FA, McClelland E, Meyer NC, Mintier GA, Moeller N, Moore T, Morikang E, Prass CE, Quintana L, Starnes SM, Schatzman RC, Brunke KJ, Drayna DT, Risch NJ, Bacon BR, Wolff RK. A novel MHC class I-like gene is mutated in patients with hereditary haemochromatosis. Nat Genet 1996;13:399-408.

79 Ruddy DA, Kronmal GS, Lee VK, Mintier GA, Quintana L, Domingo Jr R, Meyer NC, Irrinki A, McClelland EE, Fullan A, Mapa FA, Moore T, Thomas W, Loeb DB, Harmon C, Tsuchihashi Z, Wolff RK, Schatzman RC, Feder JN. A 1.1-Mb transcript map of the hereditary hemochromatosis locus. Genome Res 1997; 7:441-56.

80 Merryweather-Clarke AT, Pointon JJ, Jouanolle AM, Rochefte J, Robson KJH Geography of HFE C282Y and H63D mutations. Genet Test 2000;4:183-98.

81 Growdon JH, Locascio JJ, Corkin S, Gomez-Isla T, Hyman BT. Apolipoprotein E genotype does not influence rates of cognitive decline in Alzheimer's disease. Neurology 1996;47(2):444-8.

82 Slooter AJ, Houwing-Duistermaat JJ, van Harskamp F, Cruts $M$ Van Broeckhoven C, Breteler MM, Hofman A, Stiinen T, van Duijn CM. Apolipoprotein E genotype and progression of Alzheimer's disease: the Rotterdam Study. J Neurol 1999;246(4):304-8. 